\title{
ESTIMATION OF FUNCTIONAL RESERVES OF THE BODY AND RISK OF CARDIOVASCULAR EVENTS IN PATIENTS WITH MYOCARDIAL INFARCTION WITH COMORBID PATHOLOGY UNDERGOING REHABILITATION
}

\section{OCENA REZERW FUNKCJONALNYCH ORGANIZMU ORAZ RYZYKA ZDARZEŃ SERCOWO-NACZYNIOWYCH U PACJENTÓW PO PRZEBYTYM ZAWALE MIĘŚNIA SERCOWEGO Z ROZPOZNANIEM CHORÓB WSPÓŁWYSTĘPUJĄCYCH BĘDĄCYCH W TRAKCIE REHABILITACJI}

\author{
Larysa Levytska $^{1(\mathrm{~A}, \mathrm{~B}, \mathrm{C}, \mathrm{D}, \mathrm{E}, \mathrm{F})}$, Mykola Shved ${ }^{1(\mathrm{~A}, \mathrm{D}, \mathrm{F})}$, Mykhaylo Korda $^{1(\mathrm{D}, \mathrm{E}, \mathrm{F})}$ \\ ${ }^{1}$ Ivan Horbachevsky Ternopil State Medical University, Ukraine
}

Authors' contribution Wkład autorów: A. Study design/planning zaplanowanie badań B. Data collection/entry zebranie danych C. Data analysis/statistics dane - analiza i statystyki D. Data interpretation interpretacja danych E. Preparation of manuscript przygotowanie artykułu F. Literature analysis/search wyszukiwanie i analiza literatury G. Funds collection zebranie funduszy
Tables: 5

Figures: 1

References: 28

Submitted: 2019 Feb 26

Accepted: 2019 Jun 19

\section{Summary}

Background. Cardiovascular diseases are the leading cause of death worldwide. In Ukraine, cardiovascular mortality is $66.7 \%$.

Material and methods. We examined 371 patients with myocardial infarction (MI) with comorbid pathology who had undergone 90 days of rehabilitation. We studied the possibility of quantitative estimation of comorbid pathology, the condition of functional reserves in patients with MI, their connection with clinical markers of reduced exercise tolerance and comorbidity index.

Results. We established close correlations between the six-minute walk tests conducted on the $10^{\text {th }}, 30^{\text {th }}$ and $90^{\text {th }}$ days of rehabilitation (6MWT10,6MWT30 and 6MWT90) with age of patients (r6MWT10 = -0.199; r6MWT30 = -0.287; r6MWT90 = -0.410 P<0.05), SpO $($ r6MWT10 = -0.399; r6MWT30 $=-0.265 ;$ r6MWT90 $=-0.248 ; \mathrm{P}<0.05)$, left ventricular ejection fraction (r6MWT10 $=0.706 ;$ r6MWT30 = -0.670; r6MWT90 = -0.583; $\mathrm{P}<0.0001)$, troponin levels (r6MWT10 = -0.210 ; r6MWT30 = -0.312; $\mathrm{P}<0.05$ ); creatinine (r6MWT10 $=-0.148 ; \mathrm{P}<0,05$ ) and Charlson comorbidity index (r6MWT10 = -0.323; r6MWT30 = -0.398; r6MWT90 = $-0.427 ; \mathrm{P}<0.0001$ ).

Conclusions. Markers of reduced exercise tolerance in patients with MI were age, $\mathrm{SpO}_{2}$, ejection fraction, levels of troponin, creatinine, lymphocytes, Charlson comorbidity index.

Keywords: rehabilitation, acute myocardial infarction, Charlson comorbidity index, six-minute walk test

\section{Streszczenie}

Wprowadzenie. Choroby układu krążenia sa główna przyczyna śmiertelności na całym świecie. Na Ukrainie wskaźnik śmiertelności związanej z chorobami układu krążenia wynosi $66,7 \%$.

Materiał i metody. Badaniem objeto 371 pacjentów po przebytym zawale mięśnia sercowego (MI) z rozpoznaniem chorób współistniejących, będących w trakcie 90-dniowej rehabilitacji. Przeanalizowano możliwość ilościowego oszacowania chorób współistniejących, stanu rezerw funkcjonalnych u pacjentów po przebytym zawale mięśnia sercowego oraz związku pomiędzy klinicznymi markerami obniżonej tolerancji wysiłku a wskaźnikami zachorowalności.

Wyniki. Ścisła korelacja pomiedzy testem marszu sześciominutowego przeprowadzonym w 10, 30 i 90 dniu rehabilitacji (6MWT10, 6MWT30 i 6MWT90) a wiekiem pacjentów (r6MWT10 $=-0,199 ;$ r6MWT30 = -0,287; r6MWT90 = -0,410 P < 0,05), $\mathrm{SpO}_{2}($ r6MWT10 = -0,399; r6MWT30 $=-0,265 ;$ r6MWT90 = -0,248; P < 0,05), frakcja wyrzutowa lewej komory (r6MWT10 = 0,706; r6MWT30 = -0,670; r6MWT90 = -0,583; P < 0.0001), poziomami troponiny (r6MWT10 = -0,210; r6MWT30 = -0,312; P < 0,05); kreatyniny (r6MWT10 = -0,148; P < 0,05) oraz wskaźnikiem chorób współistniejących Charlsona (r6MWT10 = -0,323; r6MWT30 = -0,398; r6MWT90 = $-0,427 ; \mathrm{P}<0,0001)$.

Wnioski. Markerami obniżonej tolerancji wysiłku u pacjentów z MI był wiek, $\mathrm{SpO}_{2}$, frakcja wyrzutowa, poziom troponiny, kreatyniny, limfocytów oraz wskaźnik chorób współistniejących Charlsona.

Słowa kluczowe: rehabilitacja, ostry zawał mięśnia sercowego, wskaźnik chorób współistniejących Charlsona, test marszu sześciominutowego 


\section{Introduction}

Cardiovascular diseases (CVDs) are the leading cause of death throughout the world. According to the WHO, in 2016, 17.9 million people died from CVDs, 31\% of total deaths. In Ukraine, cardiovascular disease-associated deaths comprised $66.7 \%$ of the total, the highest in Europe. More than $75 \%$ of all cardiovascular deaths occur in low- and middle-income countries. Therefore, the fight against acute myocardial infarction (MI) and its consequences, and achievement of full functional recovery of patients after previous MI is particularly topical $[1,2]$.

Medical care for patients with coronary heart disease (CHD), including myocardial infarction, is often complicated by concomitant and combined pathology in these patients. Restoration of health of the cardiologic patient, especially after acute coronary events, is complicated by the effect of one or more concomitant diseases and extremely difficult $[3,4]$. The problem is magnified by the fact that most research underpinning current treatment recommendations, including post-infarction patients, focuses on uncomplicated pathology. The presence of comorbid pathology (CP) contributes to increased hospital stay duration, disability, limits the possibility of full rehabilitation, increases the number of complications after surgical interventions, affects the prognosis for life, and increases the risk of fatal outcomes [5].

The aim of this study was to quantify the risk that comorbid pathology has on patients who have experienced cardiovascular events and the state of functional reserves in patients with myocardial infarction.

\section{Material and methods}

371 patients with myocardial infarction who had undergone acute rehabilitation period at the Cardiology Department of the Ternopil University Hospital were examined and sequentially included in the local registry. The diagnosis was established based on acting protocols of treatment and rehabilitation [6, 7]. Criteria for inclusion in the study were confirmed diagnosis of MI and written informed consent of patients to participate. Acute infectious and mental illnesses, decompensation of concomitant pathology, hemodynamically significant heart defects and surgical revascularization of the infarct-dependent vessel resulted in exclusion from the study. Charlson comorbidity index (CCI) was used to evaluate the degree of comorbidity in patients with MI with concomitant pathology [8].

Drug therapy included pharmaco-invasive treatment technologies, depending on the time-window of the patients' admission. All patients without contraindications were prescribed the standard therapy recommended by acting protocols $[6,7]$, which included direct anticoagulants (low molecular weight heparin-enoxaparin at a dose of $1 \mathrm{mg} / \mathrm{kg}$ of body weight); antiplatelet drugs (acetylsalicylic acid $75 \mathrm{mg} /$ day, clopidogrel $75 \mathrm{mg} / \mathrm{day}$ ), statins (atorvastatin 40-80 mg/day); $\beta$-blockers (bisoprolol $5 \pm 1.2 \mathrm{mg} /$ day) and angiotensin-converting enzyme inhibitors (perindopril, ramipril $5 \pm 1.3 \mathrm{mg} /$ day), depending on baseline hemodynamic parameters, nitrates, narcotic analgesics. The indicated therapy was supplemented with appropriate drugs based on the existing comorbid pathology.

Morphometric parameters of intracardiac hemodynamics were evaluated using an echocardioscopic method in one-dimensional, two-dimensional, Doppler (color Doppler) pulse-wave, or continuous-wave (tissue Doppler) modes (Phillips HD 11XE, USA, 2-4 MHz sensor) according to the ultrasound heart examination recommendations given by the American Society for Echocardiography and the European Association for Echocardiography (ASE/ EAS 2015).

Electrocardiograms were registered with the help of an UTAS ECG device. Laboratory methods included a general blood test, coagulogram, biochemical blood test (glucose, bilirubin, transaminase, creatinine, urea, uric acid, and lipid blood plasma spectra (total cholesterol, triglycerides, high and low density lipoproteins). Studies were conducted in a certified laboratory unit of the Ternopil University Hospital.

Functional reserves of the cardiovascular system were determined by a method of point scoring of its individual parameters: size of the left ventricular ejection fraction more than $55 \%=1$ point, $45-55 \%=2$ points, $30-45 \%=3$ points and less than $30 \%=4$ points. In the same way, evaluation of heart failure was performed according to NYHA: FC I = 1 point, FC II $=2$ points, FC III $=3$ points and FC IV $=4$ points and the status of the cardiovascular events risk according to rehabilitation classification (Nikolaev LF, Aronov DM, 1988): FC I = 1 point, FC II = 2 points, FC III = 3 points and FC IV = 4 points. Post-infarction patients were divided into groups of low, medium and high risk, with corresponding assignments of 1,2 and 3 points $[9,10]$ based on the GRACE scale and cardiovascular events risk scale (AHA). The six-minute walk test [11] was performed and evaluated on the $10^{\text {th }}, 30^{\text {th }}$ and $90^{\text {th }}$ days after hospital admission.

Statistical analysis was performed using MS Excel 2000 and EViews 5.1 software. For quantitative variables average values and standard deviations were calculated, and absolute variables and percentage shares for each 
category were calculated for categorical variables. For quantitative variables, the statistical significances for the differences between groups of patients with concomitant pathology and non-concomitant pathology were investigated using student t-tests for independent samples. The comparability analysis on the distribution of qualitative (categorical) characteristics in the groups was carried out using $\chi^{2}$ criterion, with categorical variables presented as absolute numbers for each category. The relationships between quantitative indicators were analyzed using the standard Pearson correlation coefficient. Quantitative and categorical (in 2 categories) indicators were analyzed using point biserial correlation coefficients and quantitative and categorical indicators with $>2$ categories were measured using dispersion ANOVA analysis and coefficient (eta-squared), while the analysis of relationships between two categorical indicators was performed using the Yule's coefficient association, with the connection considered as confirmed when the coefficient of association according to the module exceeded 0.5. Using all other statistical criteria and analysis tools, the differences and connections were taken as statistically significant when $p<0.05[12,13]$.

\section{Results}

Patients with MI were $66.2 \pm 10.4$ years old, with the time from appearance of the first symptoms of the disease to time of hospitalization being on average $20.3 \pm 15.1$ hours. There were $249(67.1 \%)$ men and 122 women (32.9\%), $73(19.7 \%)$ patients were city-dwellers and 298 (80.3\%) were village-dwellers. In the overwhelming number of examined patients (93.8\%), concomitant pathology was detected: arterial hypertension affected $84.9 \%$, Diabetes mellitus $25.1 \%$, vascular pathology $24.8 \%$ and $10.8 \%$ suffered from severe cerebrovascular disease or transient ischemic attacks. Chronic arterial pathology was found in $4.9 \%$ of patients, chronic bronchopulmonary diseases in $27.8 \%$; renal pathology in $17.5 \%$, GI pathology in $15.9 \%$, and thyroid pathology in $2.4 \%$. Mortality in the acute MI period was $4.9 \%$.

The vast majority of patients admitted to the clinic (330 or 88.9\%) had a typical angina type of myocardial infarction and $370(96.0 \%)$ patients had specific ECG changes. Additional clinical manifestations in patients with acute MI were dyspnea (64.2\%), sweating (25.1\%), rhythm and conduction disorders (91.1\%), cardiac asthma (20.5\%), left ventricular aneurysm (24.8\%) and epistenotic pericarditis $(22.1 \%)$.

The analysis of exercise tolerance and rehabilitation potential in the study cohort showed that patients undergoing in-patient treatment in the cardiology department had a predominantly high degree of heart failure and reduced cardiac reserve. Thus, a six-minute walk test conducted for the examined patients on the $10^{\text {th }}$ day after admission to the clinic was $76.1 \pm 35.2 \mathrm{~m}$. On the $30^{\text {th }}$ and $90^{\text {th }}$ days the results were $133.8 \pm 49.6 \mathrm{~m}$ and 207.6 $\pm 74.1 \mathrm{~m}$, respectively. The patients' NYHA functional class was high (2.9 \pm 0.7$)$, and the risks according to the GRACE scale and American Heart Association's AAS risk scale were high and very high $(2.9 \pm 0.3$ and 2.7 \pm 0.6 , respectively). Rehabilitation and hemodynamic potential, represented by the functional class for rehabilitation classification and parameters of the left ventricular systolic function as measured with echocardiography, also indicated significant cardiovascular functional reserve depletion. Thus, the functional class according to echocardiography was $2.9 \pm 0.8$ points, and the rehabilitation classification class was $3.3 \pm 0.7$.

We concluded the following from the data. First, the examined patients made a late appeal for medical aid (20.34 \pm 15.11 hours), and accordingly, were not able to have timely revascularization of the infarct-dependent vessel. The patients were also elderly (mean age 66.16 \pm 10.41 years) and the majority had comorbidity (93.8\%). Most myocardial infarction researchers recognize that the presence of comorbid pathology can significantly negatively affect functional status and cardiovascular reserve [3-5]. These issues are often dealt with by cardiology departments in Ukraine and, accordingly, require specialized rehabilitation protocols. We therefore analyzed the basic functional parameters of patients with MI with CP and the relationship with exercise tolerance and degree of comorbidity.

Study of the basic functional characteristics of patients with MI with CP revealed metabolic disturbances, altered indicators of congestion, altered markers of myocardial necrosis of various severity degrees, as well as the presence of moderately expressed hyperdynamic syndrome of cardiovascular system functioning in the examined patients, which was compensatory in nature (Table 1).

Table 1. Basic functional parameters in patients with acute myocardial infarction $(M \pm S D)$

\begin{tabular}{|c|c|c|c|}
\hline Factor & $\begin{array}{c}\text { Patients without CP } \\
(\mathrm{M} \pm \mathrm{SD})\end{array}$ & $\begin{array}{c}\text { Patients with CP } \\
(\mathrm{M} \pm \mathrm{SD})\end{array}$ & p-value (t-test) \\
\hline HR in the acute phase of MI, bpm & $79.773 \pm 22.467$ & $84.716 \pm 25.925$ & 0.383 \\
\hline SBP in the acute phase of MI, $\mathrm{mm} \mathrm{Hg}$ & $127.045 \pm 20.797$ & $133.994 \pm 30.644$ & 0.295 \\
\hline DBP in the acute phase of MI, $\mathrm{mm} \mathrm{Hg}$ & $77.955 \pm 11.303$ & $82.464 \pm 16.093$ & 0.197 \\
\hline
\end{tabular}




\begin{tabular}{|c|c|c|c|}
\hline LVEF, \% & $51.500 \pm 6.048$ & $45.817 \pm 7.620$ & 0.001 \\
\hline RR breaths/min & 18.409 & 20.464 & 1.593 \\
\hline Erythrocytes, $\mathrm{x} 10^{12} / \mathrm{L}$ & $4.631 \pm 0.455$ & $4.306 \pm 0.697$ & 0.032 \\
\hline Hemoglobin, g/L & $135.773 \pm 25.396$ & $130.406 \pm 21.783$ & 0.268 \\
\hline Leukocytes, $\mathrm{x} 10^{9} / \mathrm{L}$ & $8.874 \pm 2.738$ & $9.317 \pm 3.745$ & 0.586 \\
\hline Lymphocytes, \% & $27.773 \pm 15.430$ & $20.257 \pm 11.751$ & 0.005 \\
\hline Thrombocytes, $\mathrm{x} 10^{9} / \mathrm{L}$ & $162.833 \pm 56.747$ & $195.099 \pm 87.633$ & 0.380 \\
\hline $\mathrm{ESR}, \mathrm{mm} / \mathrm{h}$ & $13.182 \pm 9.752$ & $17.732 \pm 14.576$ & 0.150 \\
\hline Glucose, $\mathrm{mmol} / \mathrm{L}$ & $5.635 \pm 1.304$ & $8.921 \pm 4.687$ & 0.002 \\
\hline Bilirubin, mg/L & $13.386 \pm 11.326$ & $10.760 \pm 6.931$ & 0.101 \\
\hline Creatinine, mcmol/L & $83.864 \pm 23.234$ & $106.834 \pm 89.725$ & 0.232 \\
\hline Troponin T, ng/ml & $1040.351 \pm 322.958$ & $1257.691 \pm 887.421$ & 0.014 \\
\hline $\mathrm{TC}, \mathrm{mmol} / \mathrm{L}$ & $5.211 \pm 1.689$ & $4.832 \pm 1.463$ & 0.245 \\
\hline $\mathrm{HDL}, \mathrm{mmol} / \mathrm{L}$ & $1.209 \pm 0.394$ & $1.166 \pm 0.633$ & 0.768 \\
\hline $\mathrm{LDL}, \mathrm{mmol} / \mathrm{L}$ & $3.749 \pm 1.547$ & $3.228 \pm 1.282$ & 0.098 \\
\hline Fibrinogen, g/L & $4.245 \pm 1.092$ & $4.939 \pm 4.403$ & 0.462 \\
\hline INR, u/L & $1.111 \pm 0.115$ & $1.101 \pm 0.290$ & 0.866 \\
\hline $\mathrm{SpO}_{2}, \%$ & $96.000 \pm 1.569$ & $94.199 \pm 4.155$ & 0.107 \\
\hline CCI, points & $2.259 \pm 1.324$ & $4.714 \pm 1.765$ & $<0.0001$ \\
\hline $6 \mathrm{MWT}_{10}, \mathrm{~m}$ & $128.769 \pm 24.032$ & $72.32 \pm 32.79$ & $<0.0001$ \\
\hline $6 \mathrm{MWT}_{30}, \mathrm{~m}$ & $201.154 \pm 46.07$ & $128.742 \pm 46.054$ & $<0.0001$ \\
\hline $6 \mathrm{MWT}_{90}, \mathrm{~m}$ & $307.308 \pm 79.594$ & $200 \pm 67.868$ & $<0.0001$ \\
\hline
\end{tabular}

Note. CP - comorbid pathology, HR - heart rate, SBP - systolic blood pressure, DBP - diastolic blood pressure, LVEF - left ventricular ejection fraction, RR - respiratory rate, INR - international normalized ratio, TC - total cholesterol, HDL high-density lipoproteins, LDL - low-density lipoproteins, $\mathrm{SpO}_{2}$ - arterial oxygen saturation, CCI - Charlson comorbidity index, $6 \mathrm{MWT}_{10}-$ six-minute walk test on the $10^{\text {th }}$ day of rehabilitation, $6 \mathrm{MWT}_{30}-$ six-minute walk test on the $30^{\text {th }}$ day of rehabilitation, $6 \mathrm{MWT}_{90}-$ six-minute walk test on the $90^{\text {th }}$ day of rehabilitation

Glycemic levels, the number of erythrocytes and lymphocytes in the peripheral blood, as well as the concentration of a specific marker of troponin T myocardial necrosis differed significantly in patients with MI, which developed in a background of concomitant pathology in comparison with patients without comorbidity, indicating a deeper expression of metabolic changes and the exhaustion of the adaptive capacity of the body. Tests of physical activity tolerance (6MWT on the $10^{\text {th }}, 30^{\text {th }}$ and $90^{\text {th }}$ days of rehabilitation) and left ventricular ejection fraction, reflecting the degree of violation of the systolic function of the heart were also relatively lower in patients with comorbidity.

In order to detect early prognostic markers of the response to the motor regimen expansion in post-infarction patients, the relationships between the results of the six-minute walk test at the stages of rehabilitation with functional clinical, laboratory and hemodynamic parameters were analyzed. We found that $6 \mathrm{MWT}_{10}$ was directly correlated with systolic blood pressure (SBP) in the first day of MI, the number of lymphocytes in peripheral blood, levels of total cholesterol (TC), low-density lipoprotein ( $\mathrm{LDL}$ ), oxygen saturation $\left(\mathrm{SpO}_{2}\right.$ ). Left ventricular ejection fraction (LVEF) was inversely correlated with age, frequency of respiratory movements (RR), number of leukocytes in peripheral blood, levels of aspartate aminotransferase (AAT), creatinine, troponin T and Charlson comorbidity index (CCI) (Table 2).

Table 2. Dependence of $6 \mathrm{MWT}_{10}$ on clinical functional indices in patients with MI with comorbid pathology

\begin{tabular}{|c|c|c|c|}
\hline Index & Correlation & T-criteria & p-value \\
\hline Age, years & -0.199 & -2.765 & 0.006 \\
\hline SBP in the first day of MI, $\mathrm{mm} \mathrm{Hg}$ & 0.179 & 2.477 & 0.014 \\
\hline LVEF, \% & 0.670 & 10.573 & $<0.0001$ \\
\hline $\mathrm{RR}$, breaths/min & -0.318 & -4.543 & $<0.0001$ \\
\hline Hemoglobin, g/L & 0.053 & 0.716 & 0.475 \\
\hline Leukocytes, $\mathrm{x} 10^{9} / \mathrm{L}$ & -0.156 & -2.128 & 0.035 \\
\hline SBP in the first day of MI, $\mathrm{mm} \mathrm{Hg}$ & 0.179 & 2.477 & 0.014 \\
\hline Stab, \% & -0.056 & -0.753 & 0.452 \\
\hline
\end{tabular}




\begin{tabular}{|c|c|c|c|}
\hline $\mathrm{ESR}, \mathrm{mm} / \mathrm{h}$ & -0.07 & -0.943 & 0.347 \\
\hline Lymphocytes, \% & 0.303 & 4.287 & $<0.0001$ \\
\hline Glucose, $\mathrm{mmol} / \mathrm{L}$ & -0.136 & -1.836 & 0.068 \\
\hline AAT, mmol/L & -0.288 & -4.084 & $<0.0001$ \\
\hline Creatinine, mcmol/L & -0.148 & -2.035 & 0.043 \\
\hline Fibrinogen, g/L & 0.023 & 0.312 & 0.756 \\
\hline Troponin T, ng/ml & -0.21 & -2.437 & 0.016 \\
\hline $\mathrm{TC}, \mathrm{mmol} / \mathrm{L}$ & 0.195 & 2.634 & 0.009 \\
\hline $\mathrm{HDL}, \mathrm{mmol} / \mathrm{L}$ & 0.131 & 1.678 & 0.095 \\
\hline $\mathrm{LDL}, \mathrm{mmol} / \mathrm{L}$ & 0.213 & 2.823 & 0.005 \\
\hline $\mathrm{SpO}_{2}, \%$ & 0.399 & 5.766 & $<0.0001$ \\
\hline CCI, points & -0.323 & -4.658 & $<0.0001$ \\
\hline
\end{tabular}

Note. CP - comorbid pathology, HR - heart rate, SBP - systolic blood pressure, LVEF - left ventricular ejection fraction, RR - respiratory rate, ESR - erythrocyte sedimentation rate, AAT - aspartate aminotransferase, TC - total cholesterol, HDL - high-density lipoproteins, LDL - low-density lipoproteins, $\mathrm{SpO}_{2}$ - arterial oxygen saturation, CCI - Charlson comorbidity index

We measured the same variables on the $30^{\text {th }}$ day of patient treatment (Table 3). $6 \mathrm{MWT}_{30}$ was directly correlated with LVEF, $\mathrm{SpO}_{2}$ the number of lymphocytes in the peripheral blood, the levels of total cholesterol, low-density lipoproteins. 6MWT ${ }_{30}$ was inversely correlated with age, heart rate, respiratory frequency, AAT levels, troponin $\mathrm{T}$ and comorbidity index.

Table 3. Dependence of $6 \mathrm{MWT}_{30}$ on clinical functional indices in patients with MI with comorbid pathology

\begin{tabular}{|c|c|c|c|}
\hline Index & Correlation & T-criteria & p-value \\
\hline Age, years & -0.287 & -3.955 & $<0.0001$ \\
\hline HR in acute period of MI, bpm & -0.259 & -3.54 & 0.001 \\
\hline SBP in the acute period of MI, $\mathrm{mm} \mathrm{Hg}$ & 0.129 & 1.722 & 0.087 \\
\hline LVEF, \% & 0.583 & 8.394 & $<0.0001$ \\
\hline RR, breaths/min & -0.357 & -5.014 & $<0.0001$ \\
\hline Hemoglobin, g/L & 0.018 & 0.23 & 0.818 \\
\hline Leukocytes, $\mathrm{x} 10^{9} / \mathrm{L}$ & -0.003 & -0.035 & 0.972 \\
\hline Stab, \% & 0.008 & 0.105 & 0.917 \\
\hline $\mathrm{ESR}, \mathrm{mm} / \mathrm{h}$ & -0.148 & -1.954 & 0.052 \\
\hline Lymphocytes, $\%$ & 0.278 & 3.767 & $<0.0001$ \\
\hline Glucose, $\mathrm{mmol} / \mathrm{L}$ & -0.078 & -1.001 & 0.318 \\
\hline AAT, mmol/L & -0.209 & -2.803 & 0.006 \\
\hline Creatinine, $\mathrm{mcmol} / \mathrm{L}$ & -0.086 & -1.129 & 0.261 \\
\hline Fibrinogen, g/L & -0.034 & -0.438 & 0.662 \\
\hline Troponin, ng/ml & -0.312 & -3.616 & $<0.0001$ \\
\hline $\mathrm{TC}, \mathrm{mmol} / \mathrm{L}$ & 0.254 & 3.362 & 0.001 \\
\hline $\mathrm{HDL}, \mathrm{mmol} / \mathrm{L}$ & 0.141 & 1.755 & 0.081 \\
\hline $\mathrm{LDL}, \mathrm{mmol} / \mathrm{L}$ & 0.319 & 4.256 & $<0.0001$ \\
\hline $\mathrm{SpO}_{2}, \%$ & 0.265 & 3.522 & 0.001 \\
\hline CCI, points & -0.398 & -5.718 & $<0.0001$ \\
\hline
\end{tabular}

Note. CP - comorbid pathology, HR - heart rate, SBP - systolic blood pressure, LVEF - left ventricular ejection fraction, RR - respiratory rate, ESR - erythrocyte sedimentation rate, AAT - aspartate aminotransferase, TC - total cholesterol, HDL - high-density lipoproteins, LDL - low-density lipoproteins, $\mathrm{SpO}_{2}$ - arterial oxygen saturation, CCI - Charlson comorbidity index

In the analysis of $6 \mathrm{MWT}_{90}$ (Table 4), we found that this parameter was directly related to systolic blood pressure, left ventricular ejection fraction, the number of lymphocytes in the peripheral blood, the levels of cholesterol, low-density lipoproteins, $\mathrm{SpO}_{2}$, but inversely correlated with age, heart rate, respiratory rate and comorbidity index. 
Table 4. Dependence of $6 \mathrm{MWT}_{90}$ on clinical functional indices in patients with MI with comorbid pathology

\begin{tabular}{|c|c|c|c|}
\hline Index & Correlation & T-criteria & p-value \\
\hline Age, years & -0.41 & -5.892 & $<0.0001$ \\
\hline HR in the first day of MI, bpm & -0.179 & -2.386 & 0.018 \\
\hline SBP in the first day of MI, $\mathrm{mm} \mathrm{Hg}$ & 0.205 & 2.741 & 0.007 \\
\hline LVEF, \% & 0.583 & 8.394 & $<0.0001$ \\
\hline RR, breaths/min & -0.298 & -4.067 & $<0.0001$ \\
\hline Hemoglobin, g/L & 0.115 & 1.494 & 0.137 \\
\hline Leukocytes, $\mathrm{x} 10^{9} / \mathrm{L}$ & 0.034 & 0.436 & 0.664 \\
\hline Stab, \% & -0.057 & -0.735 & 0.463 \\
\hline $\mathrm{ESR}, \mathrm{mm} / \mathrm{h}$ & -0.171 & -2.255 & 0.025 \\
\hline Lymphocytes, \% & 0.294 & 3.993 & $<0.0001$ \\
\hline Glucose, $\mathrm{mmol} / \mathrm{L}$ & -0.112 & -1.441 & 0.151 \\
\hline $\mathrm{AAT}, \mathrm{mmol} / \mathrm{L}$ & -0.105 & -1.378 & 0.17 \\
\hline Creatinine, $\mathrm{mcmol} / \mathrm{L}$ & -0.135 & -1.771 & 0.078 \\
\hline Fibrinogen, g/L & -0.014 & -0.178 & 0.859 \\
\hline Troponin, ng/ml & -0.072 & -0.788 & 0.432 \\
\hline $\mathrm{TC}, \mathrm{mmol} / \mathrm{L}$ & 0.202 & 2.627 & 0.009 \\
\hline $\mathrm{HDL}, \mathrm{mmol} / \mathrm{L}$ & 0.111 & 1.371 & 0.172 \\
\hline $\mathrm{LDL}, \mathrm{mmol} / \mathrm{L}$ & 0.285 & 3.74 & $<0.0001$ \\
\hline $\mathrm{SpO}_{2}, \%$ & 0.248 & 3.255 & 0.001 \\
\hline CCI, points & -0.427 & -6.186 & $<0.0001$ \\
\hline
\end{tabular}

Note. CP - comorbid pathology, HR - heart rate, SBP - systolic blood pressure, LVEF - left ventricular ejection fraction, RR - respiratory rate, ESR - erythrocyte sedimentation rate, AAT - aspartate aminotransferase, TC - total cholesterol, HDL - high-density lipoproteins, LDL - low-density lipoproteins, $\mathrm{SpO}_{2}$ - arterial oxygen saturation, CCI - Charlson comorbidity index

As our results show, most of these dependency factors are repeated at all three stages of rehabilitation, and therefore their significant impact on exercise tolerance during a 90-day period of the cardio-rehabilitation program is evident. In summary, we can conclude that patients with MI with comorbid pathology and high indices of age, respiratory rate, heart rate, levels of AAT, creatinine, troponin T and CCI, as well as low indices of systolic blood pressure on the first day of $\mathrm{MI}$, levels of cholesterol, low-density lipoproteins and $\mathrm{SpO}_{2}$ and LVEF have significantly lower tolerance to physical activity at all stages of rehabilitation. Therefore, the above parameters can be considered excellent functional clinical, hemodynamic and laboratory markers of reduced exercise tolerance and can be used to measure the response to increased physical activity as well as predict the tolerability of rehabilitation measures in patients with myocardial infarction in combination with comorbid pathology.

The Charlson comorbidity index is a special marker highly correlated with functional clinical, hemodynamic and laboratory indices and indices of exercise tolerance. This index is obviously superior to other multi-morbidity indices due to the relative simplicity of its definition and validity when evaluating the degree of comorbidity in many clinical trials [15-17]. The present study, together with previous studies [18, 19], confirmed the possibility of using the CCI to quantify the degree of comorbidity in patients with myocardial infarction with different comorbid pathology and predict exercise tolerance responses during rehabilitation stages.

\section{Discussion}

The process of rehabilitation of a patient with MI with CP is a complex multi-level task. Moreover, the higher the degree of comorbidity of the patient and the more systems affected by pathological processes that developed prior to the myocardial infarction, the more difficult is the task of predicting the patient's response to increased physical activity. In this regard, patients with comorbidity, especially the elderly and those with many comorbid conditions, as a rule, are deprived of the possibility of active rehabilitation. However, studies suggest that all groups of patients with acute cardiovascular disease, independent of the degree of comorbidity, benefit from cardiopulmonary rehabilitation. Therefore, the presence of comorbid pathology should not interfere with the implementation of rehabilitation programs in such patients [20,21] and, of course, the process of cardiorehabilitation should not impair the general functional state of the body. 
Approaches to the rehabilitation process in comorbid patients should be different from standard rehab programs, since the body's response to the standard load in such patients may be inadequate, hence the need for an active search of highly specific markers and valid methods of risk stratification for cardiovascular events (CVE) in the presence of multimorbid conditions. This requires a weighted integrated approach with an estimate of total risk [22-24]. In this plan, the Charlson comorbidity index and the six-minute walking test seem promising as rather universal combinations of assessment of degree of comorbidity and exercise tolerance. These two indicators of the general condition of a patient have a strong evidence base for the reliability of the estimated potential for various diseases [8,25]. Our previous studies analyzed the relationship of CCI and 6MWT with the main functional indicators of patients with MI in combination with arterial hypertension, diabetes mellitus, pulmonary pathology and other diseases, and also the trends observed in the evaluation of these markers of the rehabilitation potential [19,26-28]. In this study, we searched not only early markers for the reduction of overall function of the patient with MI with CP and their rehabilitation potential, but also the possibility of using CCI and 6MWT as integral calculators of the total risk of a comorbid patient.

Previous studies of Charlson comorbidity indices at different values of ejection fraction and 6MWT at rehabilitation stages revealed that the maximum correlation between specificity and sensitivity was observed at $\mathrm{CCI}>2$. Evaluation of the dependence of comorbidity index on the left ventricular ejection fraction showed that individuals with a higher degree of comorbidity (CCI > 2) had significantly lower values of left ventricle systolic function (LVEF < 46.5\%), with 83\% specificity and 50\% sensitivity, with the predictive value of a positive result being 98\% (Table 5, Figure 1).

Table 5. Matrix of sensitivity and specificity determination of comorbidity index at different values of ejection fraction

\begin{tabular}{|c|c|c|c|}
\hline & Sensitivity & $\begin{array}{c}\text { Comorbidity index } \\
\text { specificity }\end{array}$ & $\begin{array}{c}\text { Prognostic value of } \\
\text { positive result }\end{array}$ \\
\hline 42.5 & 0.241 & 1 & 1 \\
\hline 46.5 & 0.499 & 0.833 & 0.983 \\
\hline 54.5 & 0.893 & 0.278 & 0.960 \\
\hline 55.5 & 0.921 & 0.278 & 0.962 \\
\hline
\end{tabular}

Note. $95 \%$ confidence interval (0.573-0.807), $p=0.007$

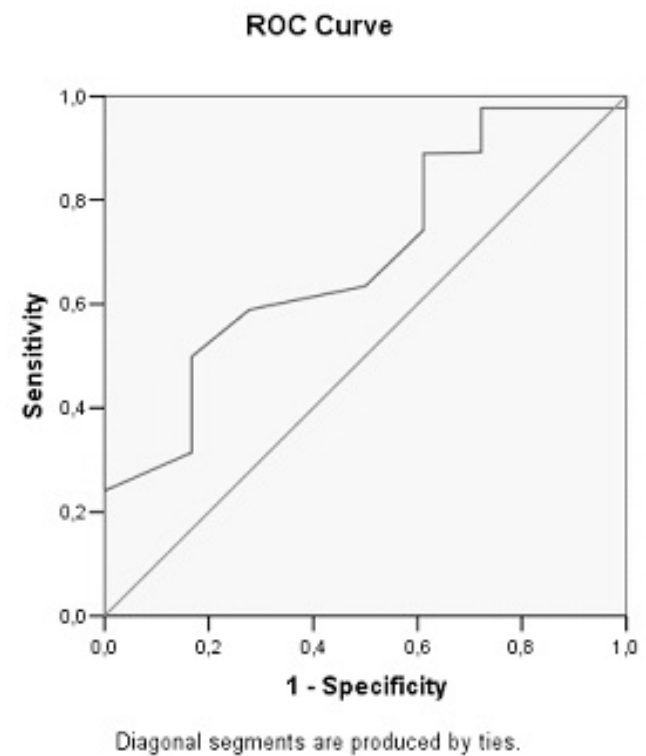

Figure 1. ROC-curve of sensitivity and specificity of comorbidity index with different values of ejection fraction Note. Area under the curve $68.96 \%$, standard error $0.060 ; p=0.007$

In this study, we analyzed the interdependence of the Charlson comorbidity index and the six-minute walk test at different stages of rehabilitation. It turned out that $6 \mathrm{MWT}_{10}, 6 \mathrm{MWT}_{30}$ and $6 \mathrm{MWT}_{90}$, which reflect the exercise tolerance, respectively, in the acute, early and late outpatient phases of the rehabilitation process, were significantly lower in patients with a higher degree of comorbidity. The maximum specificity (89\%) and the prognostic value of a positive result (98\%) for $6 \mathrm{MWT}_{10}$ with $\mathrm{CCI}>2$, was observed at $62.5 \mathrm{~m}$. We therefore recommend this target distance for passing a six-minute test on the $10^{\text {th }}$ day of rehabilitation of post-infarction 
patients when a degree of Charlson comorbidity is above 2 points. For $6 \mathrm{MWT}_{30}$, the maximum specificity (94\%) and the predictive value of a positive result (99\%) were obtained with a 6MWT ${ }_{30}$ value of $103.5 \mathrm{~m}$. Accordingly, the target six-minute walk test level by the end of the first month of the rehabilitation period in patients with MI with the CCI > 2 can be considered $103.5 \mathrm{~m}$. And for $6 \mathrm{MWT}_{90}$, the maximum specificity (59\%) and predictive value of the positive result (96\%) were obtained at the value of $199 \mathrm{~m}$. The target value of $6 \mathrm{MWT}$ by the end of the first month of the rehabilitation period in patients with MI with CCI > 2 is $199 \mathrm{~m}$.

In summary, our results suggest that the Charlson comorbidity index and the six-minute walk test are reliable prognostic markers of exercise tolerance in patients with MI with comorbid pathology at all stages of the rehabilitation process.

\section{Conclusions}

In the 90-day period of post-infarction patient rehabilitation, markers of reduced exercise tolerance were age, respiratory rate, systolic blood pressure, levels of troponin, creatinine, AAT as well as the number of lymphocytes in peripheral blood, levels of cholesterol, low-density lipoproteins, and $\mathrm{SpO}_{2}$. These indicators of the functional state of comorbid patients with MI should be used with the aim of preliminary screening to predict the tolerance of rehabilitation measures and control of the response to increased physical activity.

The Charlson comorbidity index and the six-minute walk test at certain stages of rehabilitation should be considered integral specific markers of the functional state of the body in patients with myocardial infarction with concomitant pathology. Target values of 6MWT in patients with MI with CCI > 2 can be considered: on the $10^{\text {th }}$ day of rehabilitation $32.5 \mathrm{~m}$, by the end of the first month of the rehabilitation period $-103.5 \mathrm{~m}$ and on the $90^{\text {th }}$ day $-199 \mathrm{~m}$.

\section{Disclosures and acknowledgements}

The results presented in the report are part of the research carried out within the framework of the research project entitled "Comprehensive approach to the control of symptoms, direct and long-term prognosis in conditions of comorbid pathology in the clinic of internal diseases and the practice of a family doctor". The consent for its implementation was provided by the Bioethics Committee for Scientific Research of Ivan Horbachevsky Ternopil National Medical University (extract from the report No. 47 of October 19, 2018).

\section{References:}

1. World Health Organization [Internet]. Geneva: World Health Organization. Cardiovascular diseases (CVDs) [cited 2019 Jan 27]. Available from: https://www.who.int/news-room/fact-sheets/detail/cardiovascular-diseases-(cvds)

2. Moroz DM. [Problems of health and medical care and a model of improvement in modern conditions: a manual for cardiologists, rheumatologists, therapists, health organizers and general practitioners]. In: Kovalenko VM, Kornatsky VM., editors. Institute of Cardiology of M.D. Strazhesko of the AMS of Ukraine. Kyiv: Hordon Printing House; 2016 (in Ukrainian).

3. Kuznietsova LP, Bohoslav TV, Reshetilov YI, Bondar MV. [Peculiarities of the management of patients with comorbid pathology in the clinic of internal diseases]. Zaporozhye Medical Journal. 2015; 5(92): 69-73 (in Ukrainian).

4. Campbell-Scherer D. Multimorbidity: a challenge for evidence-based medicine. Evid. Based Med. 2010; 15(6): 165-6. https://doi.org/10.1136/ebm1154

5. Caughey GE, Ramsay EN, Vitry AI, Gilbert AL, Luszcz MA, Ryan P, et al. Comorbid chronic diseases, discordant impact on mortality in older people: a 14-year longitudinal population study. J. Epidemiol. Community Health. 2010; 64(12): 1036-1042. https://doi.org/10.1136/jech.2009.088260

6. Ibanez B, James S, Agewall S, Antunes MJ, Bucciarelli-Ducci C, Bueno H, et al. 2017 ESC guidelines for the management of acute myocardial infarction in patients presenting with ST-segment elevation: the task force for the management of acute myocardial infarction in patients presenting with ST-segment elevation of the European Society of Cardiology (ESC). European Heart Journal. 2018; 39(2): $119-177$. https://doi.org/10.1093/eurheartj/ehx393

7. Roffi M, Patrono C, Collet JP, Mueller C, Valgimigli M, Andreotti F, et al. 2015 ESC guidelines for the management of acute coronary syndromes in patients presenting without persistent ST-segment elevation: task force for the management of acute coronary syndromes in patients presenting without persistent ST-segment elevation of the European Society of Cardiology (ESC). European Heart Journal. 2016; 37(3): 267-315. https://doi.org/10.1093/eurheartj/ehv320 
8. Charlson ME, Pompei P, Ales KL, MacKenzie CR. A new method of classifying prognostic comorbidity in longitudinal studies: development and validation. Journal Chronic Disease. 1987; 40(5): 373-383. https://doi.org/10.1016/0021-9681(87)90171-8

9. Shved MI, Levytska LV. [Modern strategies of restorative treatment and rehabilitation of patients with myocardial infarction]. 3rd edition. Kyiv: Medknyha; 2015 (in Ukrainian).

10. Shved M, Tsuglevych L, Kyrychok I, Boiko T, Levytska L. [Cardioreabilitation peculiarities and correction of violations of sistolic, diasolic function and heart rate variability in patients with acute coronary syndrome and coronary artery revascularization]. Georgian Medical Journal. 2017; 24(4): 46-53 (in Russian).

11. Bellet RN, Francis RL, Jacob JS, Healy KM, Bartlett HJ, Adams H, et al. Repeated six-minute walk tests for outcome measurement and exercise prescription in outpatient cardiac rehabilitation: a longitudinal study. Arch Phys Med Rehabil. 2011; 92(9): 1388-1394. https://doi.org/10.1016/j.apmr.2011.04.014

12. Utkin VA. Methodological aspects of the mathematical and statistical analysis of medical data - part 2. Attributive statistics in medical research. Medical Journal of the North Caucasus. 2009; 3(15): 70-75.

13. Pett MA. Nonparametric statistics for health care research: statistics for small samples and unusual distributions. Thousand Oaks, CA: Sage Publications; 1997.

14. Grolla DL, Tob T, Bombardierc C, Wright JG. The development of a comorbidity index with physical function as the outcome. J Clin Epidemiol. 2005; 58(6): 595-602.

15. Deyo RA, Cherkin DC, Ciol MA. Adapting a clinical comorbidity index for use with ICD-9-CM administrative databases. J Clin Epidemiol. 1992; 45(6): 613-619. https://doi.org/10.1016/0895-4356(92)90133-8

16. Miller MD, Towers A. Manual of guidelines for scoring the cumulative illness rating scale for geriatrics (CIRS-G). Pittsburg, Pa: University of Pittsburgh; 1991.

17. Rozzini R, Frisoni GB, Ferrucci L, Barbisoni P, Sabatini T, Ranieri P, et al. Geriatric index of comorbidity: validation and comparison with other measures of comorbidity. Age Ageing. 2002; 31(4): $277-285$. https://doi.org/10.1093/ageing/31.4.277

18. Shved MI, Levytska LV. [Modern strategies of treating patients with acute coronary syndrome]. Kyiv: Publishing House Medknyha; 2018. p. 176 (in Ukrainian).

19. Shved MI, Levytska LV. [Approaches to the assessment of risks and functional reserves of the cardiovascular system in patients with myocardial infarction with comorbid pathology, who are in the acute period of cardio-rehabilitation]. World of Medicine and Biology. 2018; 4(66): 124-130 (in Ukrainian). https://doi.org/10.26724/2079-8334-2018-4-66-124-130

20. Listerman J, Bittner V, Sanderson B, Brown T. Cardiac rehabilitation outcomes: impact of comorbidities and age. J Cardiopulm Rehabil Prev. 2011; 31(6): 342-348. https://doi.org/10.1097/hcr.0b013e31822f189c

21. Simić-Panić D, Bošković K, Milićević M, Rabi Žikić T, Cvjetković Bošnjak M, Tomašević-Todorović S, et al. The impact of comorbidity on rehabilitation outcome after ischemic stroke. Acta Clin Croat. 2018; 57(1): 5-15. https://doi.org/10.20471/acc.2018.57.01.01

22. Rashid M, Kwok CS, Gale CP, Doherty P, Olier I, Sperrin M, etal. Impact of co-morbid burden on mortality in patients with coronary heart disease, heart failure and cerebrovascular accident: a systematic review and meta-analysis. Eur Heart J Qual Care Clin Outcomes. 2017; 3(1): 20-36. https://doi.org/10.1093/ehjqcco/qcw025

23. Danilovic A, Ferreira TAC, Maia GVA, Torricelli FCM, Mazzucchi E, Nahas WC, et al. Predictors of surgical complications of nephrectomy for urolithiasis. Int Braz J Urol. 2019; 45(1): 100-107. https://doi.org/10.1590/S1677-5538.IBJU.2018.0246

24. Compostella L, Compostella C, Truong LV, Russo N, Setzu T, Iliceto S, et al. History of erectile dysfunction as a predictor of poor physical performance after an acute myocardial infarction. Eur J Prev Cardiol. 2017; 24(5): 460-467. https://doi.org/10.1177/2047487316686434

25. Bellet RN, Francis R, Jacob JS, Healy KM, Bartlett HJ, Adams L, et al. Repeated six-minute walk tests for outcome measurement and exercise prescription in outpatient cardiac rehabilitation: a longitudinal study. Arch Phys Med Rehabil. 2011; 92(9): 1388-1394. https://doi.org/10.1016/j.apmr.2011.04.014

26. Levytska LV. Early marker and limited factors of functional state in patients with myocardial infarction in combination with arterial hypertension. Bulletin scientific research. 2019; 1(94): 33-38. https://doi.org/10.11603/2415-8798.2019.1.9972

27. Levytska LV. [Constellation of biochemical and physical markers of the functional state of the body in patients with myocardial infarction with of sistolic and diastological arterial pressure levels and the possibility of their using in the rehabilitation process]. MCCh. 2019; 1: 92-102 (in Ukrainian). https://doi.org/10.11603/mcch.2410-681X.2019.v0.i1.10013

28. Levytska LV. Stratification risk score of cardiovascular events in patients with myocardial infarction in combination with comorbid and surgical pathology. Hospital Surgery. Journal named by L.Ya. Kovalchuk. 2019; 1: 96-104. https://doi.org/10.11603/2414-4533.2019.1.9922 